\title{
Asia (2020)
}

\section{Emika Tokunaga*}

The COVID-19 pandemic has seriously affected all the States and regions across the world since the outbreak in the beginning of the year of 2020. The Asian region is no exception. Despite the severe impacts of this disastrous pandemic, the efforts of responding to and preventing from disaster risks remain in active both at the regional and at the national level.

This article aims at showing the progress in the field of IDL practice in Asia. There are two significant regional treaties in the Asian region, namely the ASEAN Agreement on Disaster Management and Emergency Response (AADMER $)^{1}$ and the SAARC Agreement on Rapid Response to Natural Disasters. ${ }^{2}$ In particular under the AADMER the ASEAN has continuously developed further mechanisms and tools relevant to the regional cooperation of disaster management, giving due consideration to the implementation of the Sendai Framework for Disaster Risk Reduction 2015-2030 (Sendai Framework). ${ }^{3}$

\section{Southeast Asia}

\subsection{Disaster Management Framework for 2021-2025}

On 27 November 2020, the 8th Ministerial Meeting on Disaster Management (AMMDM) and the 9th Meeting of the Conference of Parties (COP) to the AADMER were jointly organized as a virtual conference. ${ }^{4}$ The participants

* Specially Appointed Associate Professor, Center for Collaborative Future Creation, Graduate School of Human Sciences, Osaka University.

** This work was supported by JSPS KAKENHI Grant Number 20Ko1313.

1 ASEAN Agreement on Disaster Management and Emergency Response, 26 July 2005, 157.

2 SAARC Agreement on Rapid Response to Natural Disasters, 11 November 2011.

3 UN 'Sendai Framework for Disaster Risk Reduction 2015-2030' (18 March 2015) UN Doc A/CONF.224/CRP.1.

4 ASEAN, 'Chairman's Statement of the Eighth Ministerial Meeting on Disaster Management (AMMDM) and Ninth Meeting of the Conference of the Parties (COP) to the ASEAN Agreement on Disaster Management and Emergency Response (AADMER)' (27 November 2O2O), available at <https://asean.org/wp-content/uploads/ADOPTED_Chairman -Statement-to-8th-AMMDM-gth-COP-to-AADMER_27-Nov-202O.pdf > last accessed (as any subsequent URL) on 9 November 2021. 
were the Secretary-General of the Association of Southeast Asian Nations (ASEAN), the ASEAn Secretariat and the ASEan Coordinating Centre for Humanitarian Assistance on disaster management (AHA Centre) as well as the ASEAN Ministers in charge of disaster management and the representatives from each ASEAN Member State. ${ }^{5}$

One of the remarkable achievements of this meeting was the adoption of the AADMER Work Programme 2021-2025 for the next five years. ${ }^{6}$ This new work programme was developed by the ASEAN Committee on Disaster Management (ACDM), which is one of the bodies responsible for overseeing and monitoring the implementation of the AADMER, with the support of the ASEAN Secretariat and the AHA Centre. ${ }^{7}$ The ACD M have so far elaborated two AADMER Work Programmes for 2010-2015 and 2016-2020 since the entry into force of the AADMER in 2009. ${ }^{8}$ The work programme for 2010-2015 was the first one to realise the purpose of the AADMER to build resilient and safe communities by 2015 with strategic components, including risk assessment, early warning and monitoring, prevention and mitigation, preparedness, response, and recovery. ${ }^{9}$ Based on the review of the achievements of this programme for three years between 2010 and 2012, the Strategy and Priorities for the AADMER Work Programme Phase 2 (2013-2015) was developed to address gaps and to enhance capacities, mechanisms and systems for disaster management and disaster risk reduction (DRR). ${ }^{10}$ The work programme $2016-2020$ was followed by these Strategy and Priorities of the Phase 2 with its eight Priority programmes in consideration of all disaster cycle. ${ }^{11}$

Considering the development of these work programmes and based on the provisions of the AADMER as a legal basis, the AAD MER Work Programme 20212025 has been elaborated by referring to the ASEAN Vision 2025 on Disaster Management, ASEAN Declaration on One ASEAN One Response: asean Responding to Disasters as One in the Region and Outside of the Region12 (OAOR Declaration), Strategy and Priorities for AAdMER Work Programme Phase 2 (2013-2015), ASEAN ICT Roadmap on Disaster Management for 2025 and beyond, and the Sendai Framework and its Asia Regional Plan

$5 \quad$ Ibid.

$6 \quad$ Ibid.

7 ASEAN, 'ASEAN Agreement on Disaster Management and Emergency Response (AADMER) Work Programme 2021-2025', available at <https://asean.org/wp-content/ uploads/2021/o8/AADMER-Work-Programme-2021-2025.pdf>, 14-15.

$8 \quad$ Ibid., 14.

$9 \quad$ Ibid., 18.

$10 \quad$ Ibid., 19.

11 Ibid., 20. 
for Implementation. ${ }^{12}$ This new work programme for the next five-year cycle from 2021 to 2025 aims at enhancing and supporting ASEAN's capabilities of disaster management and DRR through inter-sectoral cooperation, capacity building, scalable innovation, resource mobilisation, new partnerships, and stronger coordination among the ASEAN Member States. ${ }^{13}$ It is expected to be carried out through five priority programmes: (a) risk assessment and monitoring, (b) prevention and mitigation, (c) preparedness and response, (c) resilient recovery, and (d) global leadership, in order to fulfil mutual assistance and complementation among the Member States in minimising adverse effects of disasters in pursuit of safer communities and sustainable development. ${ }^{14}$ This work programme is also guided by the principles of gender and social inclusion as well as the empowerment of vulnerable groups, while adopting a web-based Monitoring and Evaluation system so that the ACDM can systematically monitor implementation progress and the achievement of results. ${ }^{15}$ One of the operationalising interventions for the outcomes and outputs of the above-mentioned five priority programmes is to develop strategies, guidelines and policies, which provide plans, legal norms, and operating programs aimed at co-implementation of prevention, response and recovery in all phases of disaster. ${ }^{16}$

As for DRR, the AADMER is widely recognized one of the most significant international instruments with a number of obligations on DRR. ${ }^{17}$ In this regard, it is worthwhile to note that the Work Programme 2021-2025 has been aligned with the Sendai Framework and its seven targets, and main priorities, which are to understand disaster risk, to strengthen disaster risk governance for disaster risk management, to invest in DRR for resilience, to enhance disaster preparedness for effective response and to realise 'Build Back Better.' ${ }^{18}$ It could be said that these priorities and targets of the Sendai Framework offers a key guidance of DRR in implementing the AADMER through the ASEAN's work programme, although the Sendai Framework is a policy documents and of no legal binding effect.

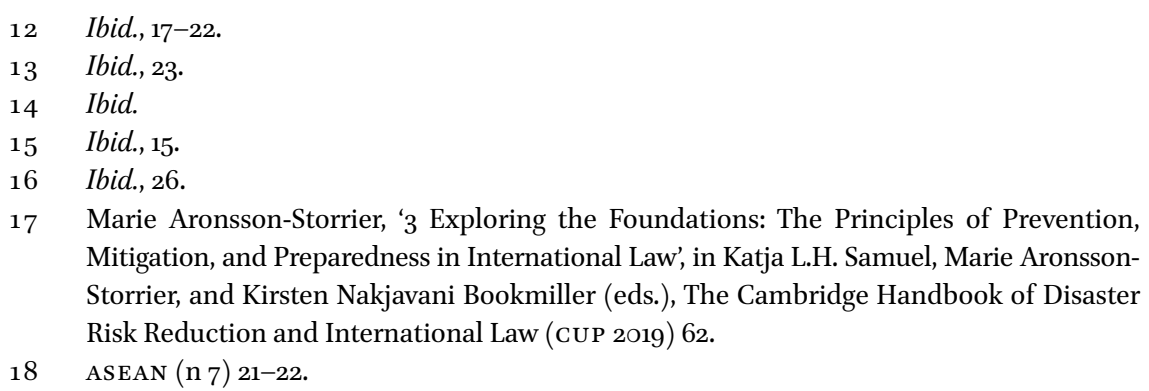




\section{Adoption of the ASEAN Declaration on The Strengthening of Adaptation to Drought}

On 10 November 2020, the ASEAN Declaration on the Strengthening of Adaptation to Drought ${ }^{19}$ was adopted. ${ }^{20}$ This declaration thereafter was commended at the 37th ASEAN Summit, which was held via video conference under the chairmanship of the Socialist Republic of Viet Nam (Viet Nam) from 11 to $15^{21}$ It shows a paradigm shift towards more adaptive drought risk management and governance. ${ }^{22}$ The Priority Programme 1 on risk assessment and monitoring and Priority Programme 2 on prevention and mitigation of the abovementioned ASEAN Disaster Management Framework for 2021-2025 were developed, considering the elaboration of the provisions of the declaration. ${ }^{23}$

The declaration includes nine paragraphs, ${ }^{24}$ which includes various actions to be taken to respond to the adverse influence of drought on livelihoods, natural resources, and economic development. ${ }^{25}$ Based on this declaration, for example, the ASEAN Member States pledges to promote a longer-term, holistic, and more strategic approach such as a regional framework on adaptations and mitigation to drought, while strengthening coordination between ASEAN sectoral bodies to effectively address slow on-set and accumulative impacts of drought on the environment, agriculture, energy, and water. ${ }^{26}$ The ASEAN Member States should further strengthen cooperation at the regional level in implementing their research and innovation development, and technology transfer in the field of climate change adaptation, water resource management, drought risks, preservation, and conservation. ${ }^{27}$

19 ASEAN Declaration on the Strengthening of Adaptation to Drought, 10 November 2020, available at <https://asean.org/the-asean-declaration-on-the-strengthening-ofadaptation-to-drought $/>$.

$20 \quad$ Ibid., 4.

21 ASEAN, 'Chairman's Statement of the 37th ASEAN Summit, Ha Noi, 12 November 2020, Cohesive and Responsive', available at <https://asean.org/wp-content/uploads/ 43-Chairmans-Statement-of-37th-ASEAN-Summit-FINAL.pdf>, paras. 1 and 72. See, ASEAN Viet Nam 2020, 'Summits' <https://www.asean202o.vn/web/asean_en/cac-hoi -nghi-cap-cao>.

ASEAN, 'ASEAN, UNESCAP launch Building Resilience to Drought in South-East Asia report' (27 November 2020), available at <https://asean.org/asean-unescap-launchbuilding-resilience-to-drought-in-south-east-asia-report/ > .

Ibid. 


\subsection{The Launch of the EU-SAHA}

The Integrated Programme in Enhancing the Capacity of AHA Centre and ASEAN Emergency Response Mechanisms (EU-SAHA) was initiated in early $2020 .{ }^{28}$ The EU offers a EUR 10 million grant to support the AHA Centre in implementing this programme. This new initiative is expected to enhance the capacity and sustainability of the AHA Centre at the operational level in disaster monitoring and emergency response, while strengthening the mechanisms for the ASEAN Leadership to Respond-As-One through innovation in disaster management. $^{29}$

This programme also aims to build upon and complement several past and planned EU supported activities in the ASEAN region, including the EU-ASEAN enhanced dialogue facility and the ASEAN peat land management programme to mitigate forest fires. ${ }^{30}$ The objective of this programme is to contribute to the goal of the AADMER to achieve a substantial reduction of disaster losses in lives and in the economic, social, physical and environmental assets of ASEAN Member States, while assisting joint responses to disaster emergencies through concerted national efforts and intensified cooperation both at the regional and international level. ${ }^{31}$ The specific objectives includes strengthening the capacity and sustainability of the AHA Centre to achieve operational excellence in disaster monitoring and emergency response and to enhance mechanisms for ASEAN Leadership to Respond-As-One through excellence and innovation in disaster management. ${ }^{32}$

\section{$2.4 \quad$ The Launch of the ASCEND Programme}

On 22 September 2020, the AHA Centre launched the 'ASEAN Standards and Certification for Experts in Disaster Management (ASCEND)' project with the support of the Republic of Korea (ROK). ${ }^{33}$ The ASCEND is an initiative to enhance the quality of human resources in disaster management though the establishment of a common set of standard skills and competencies with its

28 AHA Centre, 'The Column: The AHA Centre News Bulletin, Vol. 68, December 2020', available at <https://ahacentre.org/wp-content/uploads/2021/o1/The-Column-Vol-68-REV3-1 .pdf $>, 12$.

29 AHA Centre, 'Press Release - EU Announces Support to Humanitarian and Emergency Response in ASEAN' (27 January 2020), available at < https://ahacentre.org/press-release/ eu-saha-programme-launch/>.

$30 \quad$ Ibid.

$31 \quad$ Ibid.

$32 \quad$ Ibid.

33 AHA Centre, 'Press Release - aHA Centre and The Republic Of Korea Launch The Ascend Programme To Enhance Professionalism In Disaster Management In The ASEAN Region' (22 September 2020), available at <https://ahacentre.org/press-release/ascend-launch/>. 
validation process. ${ }^{34}$ The first phase of ASCEND development from 2016 to 2020 was led by the National Disaster Management Authority of Indonesia through its Professional Certification Agency on Disaster Management in collaboration with the AHA, with the endorsement of the ACDM in 2018.35 The ROK confirmed its support for the second phase of the ASCEND project in the next three years from 2020 to $2023 \cdot{ }^{36}$

The purpose of the ASCEND is to strengthen the capacity of disaster management professionals from the ASEAN Member States by setting higher standards and quality of training in disaster management, as well as certifications for professionals based on agreed ASEAN standards. ${ }^{37}$ The ASCEND is a three-year project, to which the ROK contributes more than USD 3.3 million grant through the ASEAN-ROK Cooperation Fund, while generating a pool of professionals to mobilise assistance and resources during disasters. ${ }^{38}$ This project is also part of the AADMER Work Programme $2021-2025 .{ }^{39}$ It is expected that the development of the ASCEND project will contribute to the realisation of ASEAN's goal to become a global leader in disaster management by 2025 , as articulated in the ASEAN Vision 2025 on Disaster Management. ${ }^{40}$ In conducting this project the Korea National Fire Agency will provide the AHA Centre with their expert support and experience of the Korea Disaster Relief Team, which has been certified as a heavy urban Search And Rescue team by the UN International Search and Rescue Advisory Group. ${ }^{41}$

\subsection{Response to the COVID-19}

The Special Summit on the COVID-19 was held as a video conference by the ASEAN Member States on 14 April 2020.42 The milestone of this summit was

34 AHA Centre, 'ASCEND: The ASEAN Standards and Certification for Experts in Disaster Management', available at <https://ahacentre.org/wp-content/uploads/2020/12/201214 -ASCEND-Brochure.pdf $>, 1$.

Ibid., 3 .

36 Ibid.

37 ASEAN, 'ASEAN, the Republic of Korea and AHA Centre Launch the ASCEND Project to Strengthen Region's Capability in Managing Natural Disasters' (22 September 2020), available at $<$ https://asean.org/asean-the-republic-of-korea-and-aha-centre-launch-the -ascend-project-to-strengthen-regions-capability-in-managing-natural-disasters/>.

$38 \quad$ Ibid.

39 AHA Centre (n 34) 4.

40 Ibid.

41 AHA Centre (n 33).

42 ASEAN, 'Declaration of the Special ASEAN Summit on Coronavirus Disease 2019 (COVID-19)' (14 April 2020), available at <https://asean.org/wp-content/uploads/2021/o9/ FINAL-Declaration-of-the-Special-ASEAN-Summit-on-COVID-19.pdf>, 1. 
the adoption of the Declaration of the Special ASEAN Summit on Coronavirus Disease 2019 (COVID-19). ${ }^{43}$ This declaration requires each ASEAN Member State and the relevant organs and sectoral bodies of the ASEAN to conduct the extensive measures, which aim to contain the pandemic of the CoviD-19 and to protect people's lives and livelihoods, maintaining socio-economic stability among the ASEAN Member States. ${ }^{44}$

The measures include enhancing public health cooperation through the exchange of information about real time situation and individual Member State response, and strengthening the implementation of the World Health Organization (WHO) International Health Regulations (IHR 2005) ${ }^{45}$ It was also suggested in the declaration to formulate an ASEAN standard operating procedure (SOP) for public health emergencies (PHE). ${ }^{46}$ Under the agreement of the formation of the SOP on PHE in this summit, the ASEAN published ASEAN Strategic Framework for Public Health Emergencies on 10 November 2020.47 Based on the AADMER, this Framework is expected to strengthen ASEAN's preparedness, detection, response and resilience to public health emergencies in order to enhance regional health security through their cooperation. ${ }^{48}$ It will explore synergies and complementarity with existing ASEAN agreements, mechanisms and tools as well as relevant international agreements, including the ASEAN SOP for Standby Arrangements and Coordination of Joint Disaster Relief and Emergency Response Operations and the IH R 2005. ${ }^{49}$

In this special summit it was also proposed that the Member States should strengthen effective and transparent public communication including clarifications on misinformation and efforts to reduce stigmatisation and discrimination. ${ }^{50}$ They are also required to prioritise the well-being of the affected States and their people by providing appropriate assistance, taking into account collective action and coordinated policies to mitigate the economic and social impact from the pandemic. ${ }^{51}$ In these regards, from the viewpoint of the rights guaranteed by the ASEAN Human Rights Declaration (AHRD), ${ }^{52}$

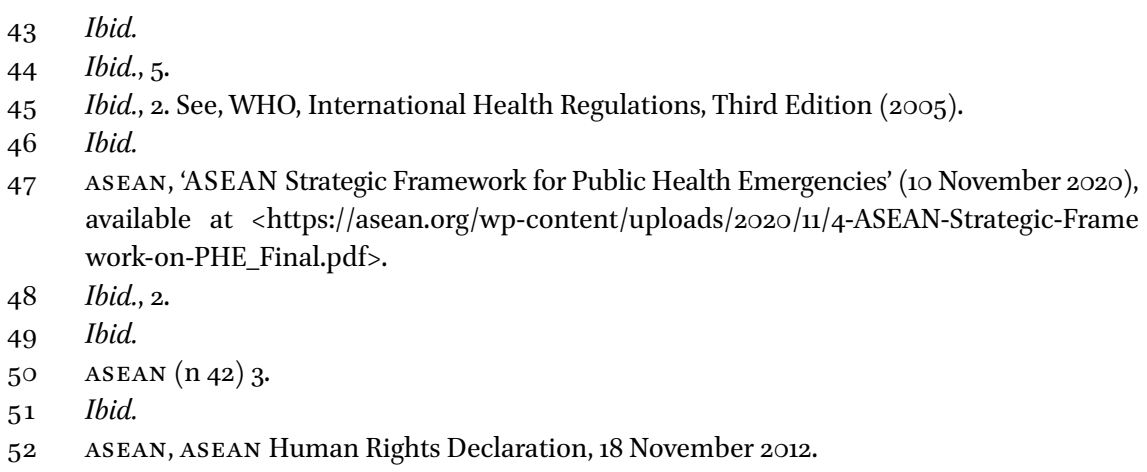


the ASEAN Intergovernmental Commission on Human Rights (AICHR) also showed their concerns about the negative effects of the pandemic of COVID-19 on the lives and the well-being of the people on 1 May 2020. ${ }^{33}$ Based on the right to health provided in Article 29 of the AHRD, the AICHR underscored that all persons at risk and infected by the CoviD-19 can access to essential healthcare services when the ASEAN Member States take protection measures. ${ }^{54}$ The AICHR also stressed the importance to promote and protect human rights, including economic, social, civil and political rights and rights of vulnerable groups as well as the rights of ASEAN Community and the people to freedom of opinion and expression in collectively mitigating and suppressing the impact of COVID-19. ${ }^{55}$

\section{3}

\section{South Asia}

There seemed to be no outstanding practice of IDL in South Asia in 2020, the South Asian Association for Regional Cooperation (SAARC) has focused on the spread of the pandemic of the COVID-19 in the region.

For example, at the proposal of Prime Minister of India, on 15 March 2020 the Leaders of the SAARC Member States gathered an online conference to discuss the measures to struggle against this infection. ${ }^{56}$ The suggestions shared by the participating States included the creation of an Emergency Fund with voluntary contributions from all Member States, the continuation of the consultation process through meetings both at the ministerial level and the experts' level, and the formulation of a comprehensive strategy at the regional level through the SAARC process and other mechanisms. ${ }^{57}$ On the other hand, the interim unit of the SAARC Disaster Management Centre made an overall

53 ASEAN, 'Press Release on Coronavirus Disease 2019 (COVID-19) by the ASEAN Intergovernmental Commission on Human Rights (AICHR)' (1 May 2020), available at <https://asean.org/press-release-on-coronavirus-disease-2019-covid-19-bythe-asean-intergovernmental-commission-on-human-rights-aichr-2/>.

54 Ibid.

55 Ibid.

56 SAARC, 'Press Release - The Leaders of the Member States of SAARC held a Video Conference to discuss measures to contain the spread of COVID-19 in the region' (16 March 2020), available at <https://www.saarc-sec.org/index.php/press-release/283-pres-release -the-leaders-of-the-member-states-of-the-south-asian-association-for-regional-coopera tion-saarc-held-a-video-conference-on-15-march-2020-to-discuss-measures-to-contain -the-spread-of-covid-19-in-the-region>.

Ibid. 
revision of their website to share the updated situations and related information on the pandemic of the COVID-19 with the SAARC States. ${ }^{58}$

\section{$4 \quad$ East Asia}

There is no regional treaty on DRR and disaster response in East Asia. Three of the States such as Japan, RoK, and the People's Republic of China (China) have advanced dialogue with each other and strengthened cooperation in the area of disaster management through periodical summits since 2003. ${ }^{59}$

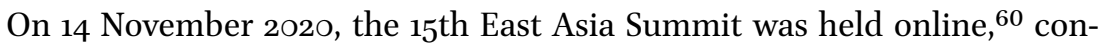
sidering the adverse impact of the COVID-19. The meeting was chaired by the Prime Minister of Viet Nam and attended by the Heads or High Representatives of the above three East Asian States as well as Australia, the Republic of India, New Zealand, the Russian Federation, the United States of America, and the ASEAn Member States. ${ }^{61}$ The UN Secretary-General, President of the World Bank Group, and the ASEAN Secretary-General were also in attendance. ${ }^{62}$ As regards natural disaster management, it was emphasised that the need to foster closer collaboration among EAS participating States and the ASEAN, to support capacities of disaster management and emergency response at the regional and sub-regional level, while addressing their disruptions to the socioeconomic development. ${ }^{63}$ It is also encouraged that the engagement between the ACDM and the national disaster management organisations of non-ASEAN EAS participating countries should be strengthened through their participation in ASEAN-led activities and projects. ${ }^{64}$

$5^{8}$ SAARC Disaster Management Centre, 'Coronavirus Disease (COVID-19) - SAARC Region', available at $<$ http://covid19-sdmc.org $>$.

59 Emika Tokunaga, 'Asia (2018)' (2019) 1 Yearbook of International Disaster Law, 338-339.

6o ASEAN, 'Chairman's Statement of the 15th East Asia Summit, Viet Nam, 14 November 2020', available at <https://asean.org/wp-content/uploads/45-Final-Chairmans-Statement-ofthe-15th-East-Asia-Summit.pdf $>, 1$.

$61 \quad$ Ibid.

62 Ibid.

63 Ibid., 5 .

64 Ibid., 6. 